\title{
Pasture silage in New Zealand - targets and current practice
}

\author{
S.W. HOWSE', P. ISHERWOOD ${ }^{2}$, D.B. MILLER', J.L. WELLS', \\ C.M. RIDDICK', N.A.THOMSON ${ }^{3}$, and D.A. CLARK ${ }^{3}$ \\ 1 Livestock Improvement Advisory, Private Bag 3016, Hamilton \\ 2 Lincoln University Analytical Laboratory, Lincoln University, Canterbury \\ 3 Dairying Research Corporation, Private Bag 3123, Hamilton
}

\begin{abstract}
Pasture silage is harvested from surplus spring pasture on many New Zealand dairy farms, for use as a supplementary feed in times of feed shortage. Targets for the quality of silage suitable for feeding to lactating dairy cows are presented, as recommended by a silage workshop held in Hamilton in 1994. National information from the Lincoln University Analytical Laboratory are presented that show that pasture silage made in the $1994 / 95$ season was well preserved. However, most of that silage had a feed quality below the target set for lactating dairy cows. Averages for DM digestibility were $65.5-67.9 \%$, estimated $\mathrm{M} / \mathrm{D}$ was $9.3-9.6$ MJ ME/kg DM, and crude protein was 14.6- $15.1 \%$. Silage-making practices were analysed, based on silage samples entered in the 1994195 Livestock Improvement Advisory silage competition. The key to making high quality pasture silage in the 1994/95 season was to harvest pasture by the first week in November. Nitrogen fertiliser may be used to produce early surplus pasture without restricting the feed supply to grazing cows. Further survey work is planned to confirm observations made, and expand on practical recommendations for making high quality pasture silage.
\end{abstract}

Keywords: dairying, feed analysis, nitrogen fertiliser, pasture, silage, silage additives

\section{Introduction}

In many overseas countries high quality pasture silage forms the base of the diet of lactating dairy cows. As feed intake and total milk production are positively associated with silage quality (Castle et al. 1980), every effort is made to ensure that optimal harvesting and preservation practices are followed.

Traditionally, New Zealand dairy farmers have viewed pasture silage somewhat differently. With supplementary feeds (including pasture silage) forming only a small proportion of the annual feed intake of cows, silage making has been mainly used to control surplus pasture during the spring, rather than to produce high quality supplementary feed for lactating cows. Silage quality has rarely been specifically sought by dairy farmers, with the exception of those who use silage to produce winter milk. Analysis of pasture silage for nutritive value has been rare.

A survey of Waikato dairy farmers carried out by Haigh (1978) illustrates the variability in New Zealand silage-making practices. Time elapsed between the last time that pasture was grazed, and cutting for silage, ranged from 3 to 10 weeks, with harvest dates ranging from late September to late December. Average crop yield was $4300 \mathrm{~kg} \mathrm{DM} / \mathrm{ha}$, with a range of 2800 to 5300 $\mathrm{kg} \mathrm{DM} / \mathrm{ha}$. There was no reported analysis of silage quality in the paper.

New Zealand dairy farmers in the 1990s are beginning to search for inexpensive sources of supplementary feed, which can be used to increase production and profit from their farming operation. Some believe that pasture silage has the potential to be a high quality and inexpensive source of supplementary feed.

This paper presents a series of targets for pasture silage of suitable quality to be fed to lactating cows. Information is presented from Lincoln University's Animal and Veterinary Sciences Department Analytical Laboratory database, to show how pasture silage made by New Zealand farmers in the 1994/95 season compares with these targets. Silage competitions run by Livestock Improvement Advisory in 3 North Island regions in the 1994/95 season provide information on the effect of management practices on silage quality.

\section{Targets for high quality pasture silage}

A silage workshop was convened in Hamilton in 1994, to evaluate current silage making practices against best known practice, and develop recommendations for New Zealand dairy farmers. The workshop included invited dairy farmers, farm advisors, scientists, university staff, and Dr. Alan Kaiser, an experienced silage researcher from Australia.

Targets for pasture silage to be fed to lactating dairy cows was one of the topics discussed at the workshop. Targets agreed upon at the workshop are presented in Table 1. 
Dry matter digestibility (DMD), energy concentration (M/D), and crude protein (CP) describe feed quality. Figures presented in Table 1 are minimum values for silage which is suitable for feeding to lactating cows. Silage not meeting these targets is likely to limit milk production if offered to lactating cows, unless the cows are being severely underfed at the time.

Dry matter content $(\mathrm{DM} \%), \mathrm{pH}$, and ammonium $\mathrm{N}$ as a percentage of total $\mathrm{N}\left(\mathrm{NH}_{3}-\mathrm{N} \%\right)$ describe the success of the silage preservation. DM\% and $\mathrm{pH}$ need to be considered together, as $\mathrm{pH}$ tends to increase as DM\% increases (Woolford 1984) Consequently, if $\mathrm{DM} \%$ is higher than the target, a higher $\mathrm{pH}$ is acceptable. A high $\mathrm{NH}_{3}-\mathrm{N} \%$ indicates that protein breakdown has occurred in the stack, an indication of the activity of undesirable bacteria in the silage.

\section{Quality of New Zealand silage - national average}

The Animal and Veterinary Sciences Group at Lincoln University offers a commercial feed analysis service through its analytical laboratory. Means and standard deviations for important silage characteristics from samples analysed over the period 1 June 1994 to 1 May 1995 are presented in Table 2. The results for silage (conventional silage from pits or stacks) are presented separately from baled silage. The information has not been derived from randomly selected sources, but represents all of the samples analysed during this period.

True DM\% is estimated by adjusting the DM\% of fresh samples oven dried at $90^{\circ} \mathrm{C}$ (CSIRO 1990). The $\mathrm{pH}$ is detemined by adding a fixed volume of water to a fresh sample of silage, and measuring the $\mathrm{pH}$ of the liquid after 2 hours. Determination of $\mathrm{NH}_{3}-\mathrm{N} \%$ is by a Kjeldahl distillation technique using a fresh sample of silage,. CP determination uses a Kjeldahl distillation technique on a freeze dried sample, with $\mathrm{CP}$ being calculated as total $\mathrm{N}$ multiplied by 6.25. Digestibility is estimated on a freeze dried sample using an in-vitro cellulase/pepsin method (McLeod \& Minson 1978), with M/D estimated from this using a standard equation (CSIRO 11960 ).

\section{Success of the preservation}

The average DM\% of silage analysed was $31 \%$; with a $\mathrm{pH}$ of 4.5. Both of these averages fall at the upper end of the targets described in Table 1. Balage had a higher average DM\% of $45 \%$, and the average $\mathrm{pH}$ was also higher, at 5.1. The $\mathrm{NH}, \mathrm{N} \%$ of both classes of 'silage was similar, at $7.1 \%$ and $9.4 \%$ respectively.

These results demonstrate that New Zealand pasture
Table 1 Targets for high quality and well preserved pasture silage

\begin{tabular}{lc}
\hline Factor Measured & Target For High Quality Silage \\
\hline DM\% (pit or stack silage) & $25-30 \%$ \\
DM\% (baled silage) & $30-35 \%$ \\
pH & $3.5-4.5$ \\
Crude Protein & $16-20 \%$ \\
NH,-N (\% of total N) & $<10 \%$ \\
Dry Matter Digestibility & $>70 \%$ \\
Estimated Energy Concentration & $>10 \mathrm{MJ}$ ME/kg DM \\
\hline
\end{tabular}

Table 2 Means (x), standard deviations (s.d.) and numbers (n) of pasture silage samples analysed at Lincoln University Analytical Laboratory (1 June $1994-1$ May, 1995)

\begin{tabular}{lcccccc}
\hline & \multicolumn{3}{c}{ Balage } & \multicolumn{3}{c}{ Silage } \\
& x & s.d. & $n$ & x & s.d. & $n$ \\
\hline DM (\%) & 45.0 & 8.8 & 160 & 31.0 & 7.5 & 459 \\
pH & 5.1 & 0.6 & 152 & 4.5 & 0.6 & 438 \\
NH,-N (\%) & 7.1 & 3.4 & 150 & 9.4 & 4.5 & 433 \\
CP (\%) & 14.6 & 3.1 & 152 & 15.0 & 2.6 & 439 \\
DMD (\%) & 66.6 & 9.5 & 158 & 67.9 & 6.2 & 459 \\
M/D & 9.3 & 1.5 & 156 & 9.5 & 1.2 & 459 \\
\hline
\end{tabular}

silages, on average, are well preserved. The $\mathrm{NH}_{3}-\mathrm{N} \%$ in both types of silage was below the target of $10 \%$, and the average $\mathrm{pH}$ of both classes of silage was good in relation to the $\mathrm{DM} \%$. The average $\mathrm{DM} \%$ of the balage was very much higher than the target of $30-35 \%$. This may indicate high losses during harvesting, as high DM\% silages have been associated with high losses in previous studies (Harrison et al. 1994).

\section{Feed quality}

The average feed quality of the silage and balage was slightly below target. Digestibility and M/D values for both silage and balage fell just below the targets established for high quality milking feed. Similarly $\mathrm{CP}$, at $15 \%$ and $14.6 \%$ for pit silage and baled silage respectively, was just below the target of $16 \%$.

Figures 1 and 2 show the distribution of both CP and M/D for silage and balage samples analysed. It is clear that many samples met'quality targets, even if the average was not quite up to that standard.

\section{Effect of management practices on silage quality}

Members of Livestock Improvement Advisory in the Waikato, Taranaki, and Manawatu/Wairarapa areas organised a silage competition for dairy 'farmers in the 1994195 season. Farmers entering the competition 
Figure 1 Crude protein in silage and balage samples 1 June 1994 - 1 May 1995

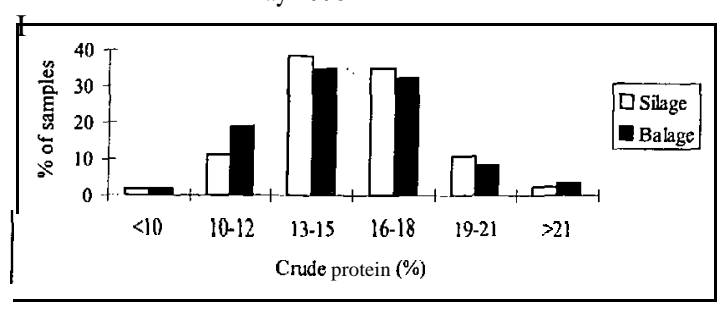

submitted a silage sample for analysis to Lincoln University Analytical Laboratory, and completed an entry form with details of the husbandry which was used in making the silage.

A total of 390 samples were entered, 90 coming from the Waikato, 232 from Taranaki, and 68 from the Manawatu/Wairarapa region. Owing to omissions of data on some entry forms, only 332 of these samples were able to be included in analyses of the effect of time elapsed between last grazing and cutting, and cutting date, on silage parameters.

\section{Competition averages}

Silage samples submitted for the competition make up a large proportion of the results presented in Table 2 . Since competition averages are very similar to those presented in Table 2, they have not been presented separately. Reference is made to regional averages in an article written by Howse (1995).

Of the samples analysed, 182 had been taken from silage ensiled in a stack or pit, ' 147 were from silage bales, and 61 were not specified. The average quantity of silage made by farmers ensiling their silage in a stack or pit was $36000 \mathrm{~kg} \mathrm{DM}$ (at $180 \mathrm{~kg} \mathrm{DM} / \mathrm{m}^{3}$ ), or 115 tonnes of fresh material based on the average DM\% of Lincoln University samples (Table 2). The average quantity of silage made by farmers making baled silage was $13000 \mathrm{~kg} \mathrm{DM}$ (at $200 \mathrm{~kg} \mathrm{DM} /$ bale), or 29 tonnes of fresh material.

The silage quality parameters mentioned in Table 1 were analysed against husbandry practices which farmers recorded on competition entry forms, and covariate analysis was used to determine the effect of management on the silage produced. Only statistically significant effects $(\mathrm{P}<0.05)$ are reported here.

\section{Cutting date}

Cutting date ranged from early September 1994 to late January 1995. Delays in cutting date reduced silage quality. The average effect of a delay in cutting date of
Figure 2 M/D of silage and balage samples | June 1994 I May 1995

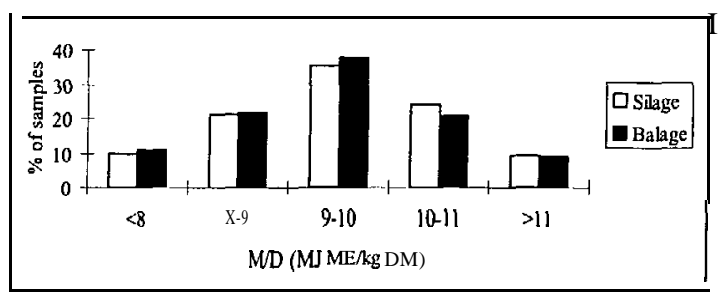

10 days included decreases in CP of $0.4-0.8 \%$, decreases in DMD of $1.0-2.5 \%$, and decreases in M/D of 0.2-0.4 MJ ME $/ \mathrm{kg}$ DM. This reflects the gradual decline in pasture quality through the spring, as the proportions of seed-head and dead material increase in pasture.

We recommend that pasture be cut for silage no later than the first week in November. If cut later than this it will be difficult to make silage with a high feed value $(>10 \mathrm{MJ} \mathrm{ME} / \mathrm{kg} \mathrm{DM})$.

\section{Time between last grazing and cutting}

The length of time elapsed between when the pasture was last grazed, and when it was cut for silage, ranged from 2 to 20 weeks. This was relatively unimportant, once the cutting date had been taken into account. The only significant effect of increasing the interval between last grazing and cutting was to reduce the $\mathrm{CP}$ content of the silage, by $0.3 \%$ for each 10 days longer that the silage was shut.

Yield of silage crops was not assessed in the competition. However, longer intervals between last grazing and when the pasture is cut are likely to increase silage yield.

\section{Time from cutting until the silage is covered}

Of samples submitted, $49 \%$ had been ensiled and covered within 24 hours ofcutting, and $85 \%$ were covered within 48 hours of cutting. The longest time elapsed between cutting and covering of the silage was 15 days.

Each day which elapsed between cutting and covering was associated with a decline in silage $\mathrm{CP}$ of $0.26 \%$, and a corresponding increase in $\mathrm{NH}_{3}-\mathrm{N}$ of $0.28 \%$.

This observation suggests that silage quality is unlikely to be badly affected by moderate delays between cutting and covering of silage. However, losses of material are increased with delays between cutting and ensiling of pasture (McDonald et al. 1968) and thus delays from cutting to covering of silage should be minimised. 


\section{Nitrogen fertiliser}

Nitrogen fertiliser was applied to pasture which was shut up for silage by $57 \%$ of those entering the competition. Urea was the most common fertiliser used, with other sources including di-ammonium phosphate, sulphate of ammonia, and animal manures. It was not possible to interpret the rates of $\mathrm{N}$ used, because ambiguity in the survey forms led to some expressing fertiliser use as $\mathrm{kg}$ fertiliser/ha, and others expressing it as $\mathrm{kg} \mathrm{N} / \mathrm{ha}$.

Silage made from N-boosted pasture had a DM\% of $33.7 \%$, which was I .6\% lower than pasture which had not been boosted with $\mathrm{N}$ fertiliser. Use of $\mathrm{N}$ fertiliser increased the amount of non-protein $\mathrm{N}$ in the silage. CP was increased by $0.8 \%$ in $\mathrm{N}$-boosted silage, to $15.4 \%$, and $\mathrm{NH}_{3}-\mathrm{N}$ was also increased, by $1.0 \%$ to $9.7 \%$.

The use of $\mathrm{N}$ fertiliser did not improve the quality of the silage. However, $\mathrm{N}$ fertiliser is likely to have improved silage yields. If the application of $\mathrm{N}$ fertiliser results in early feed surpluses on dairy farms, it will be more likely that silage will be able to be harvested by the end of the first week in November. For this reason we recommend that dairy farmers wishing to harvest pasture silage consider the use of $\mathrm{N}$ fertiliser.

\section{Silage additives}

Overseas, silage additives are used widely for silage making. In systems where silage forms most of the diet, improved animal performace is often reported from silages made using additives, largely because of increased intake of these silages by cows (Steen 1991). In the silage competitions, $19 \%$ of entries reported treating with an additive.

Samples on which additives had been used had a lower $\mathrm{pH}$ than those not ensiled with an additive (4.35 vs 4.76 ), suggesting that the additive had promoted a more rapid fermentation of the pasture once ensiled. The use of additives was not associated with any significant difference in other silage parameters.

Silage additives may be useful in ensiling pasture where a successful fermentation could be difficult to achieve, such as low DM\% pasture.

\section{Conclusions}

Most pasture silages made by New Zealand dairy farmers are well preserved. However, their quality falls short of target for a feed suitable for lactating dairy cows.

Feed quality can be improved by ensuring that pasture silage is harvested by the first week in November. The use of $\mathrm{N}$ fertiliser early in the spring will be a means of generating the early surpluses of high quality pasture required to meet this target without com- promising the feeding levels of the dairy herd.

A future silage competition is planned to confirm relationships identified in this paper, and to further explore practical opportunities for improvement in the way that New Zealand dairy farmers make pasture silage.

\section{ACKNOWLEDGEMENTS}

The authors wish to thank Rhonda Sutherland, of the Dairying Research Corporation, for her invaluable assistance in analysing the data obtained from silage competitions. The Consulting Officers and FarmWise Consultants from the Waikato, Taranaki, and Wellington/ Hawke's Bay regions are acknowledged for their help in setting up and running the regional silage competitions and associated field days. Contributors to the 1994 silage workshop are acknowledged for their help in arriving at some targets for pasture silage, and for helping to clarify the way ahead for silage extension and research in New Zealand.

\section{REFERENCES}

CSIRO 1990. Feeding standards for Australian livestock - ruminants. CSIRO Publications, Australia.

Castle, M.E.; Retter, WC.; Watson, J.N. 1980. Silage and milk production: a comparison between three grass silages of different digestibilities. Grass and forage science 53: 219-225.

Haigh, P.M. 1978. A survey of pasture silage making on factory supply dairy farms in the Central Waikato 1977-78. New Zealand journal of experimental agriculture 6: 279-283.

Harrison, J.H.; Blauwiekel, R.; Stokes, M.R. 1994. Fermentation and utilisation of grass silage. Journal of dairy science 77: 3209-3235.

Howse, S. W. 1995. Pointers from regional competitions - quality vital to silage success. New Zealand dairy exporter 71(2): 33-36.

McLeod, M.N.; Minson, D.J. 1978. The accuracy of the pepsin-cellulase technique for estimating the dry matter digestibility in vivo of grasses and legumes. Animalfeed science and technology 3: 277-287.

McDonald, P.; Henderson, A.R.; MacGregor, A.W. 1968. Chemical changes and losses during the ensilage of wilted grass. Journal of the science of food and agriculture 19: 125-I 32.

Steen, R.W.J. 199 1. Recent advances in the use of silage additives for dairy cattle. In: Ed C.S. Mayne. Management issues for the grassland farmer in the 1990s. Occasional Symposium No. 25, British Grassland Society: 87-101.

Woolford, M.K. 1984. The silage fermentation. Marcel Dekker Inc, New York. 